ppi $201502 Z U 4645$

Esta publicación científica en formato digital es continuidad de la revista impresa ISSN-Versión Impresa 0798-1406 / ISSN-Versión on line 2542-3185Depósito legal pp $197402 Z$ U34

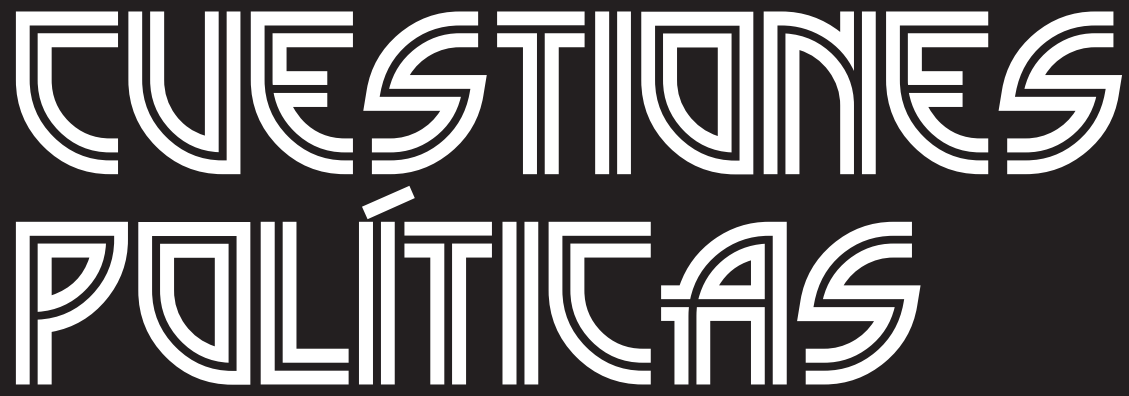

Instituto de Estudios Políticos y Derecho Público "Dr. Humberto J. La Roche" de la Facultad de Ciencias Jurídicas y Políticas de la Universidad del Zulia Maracaibo, Venezuela
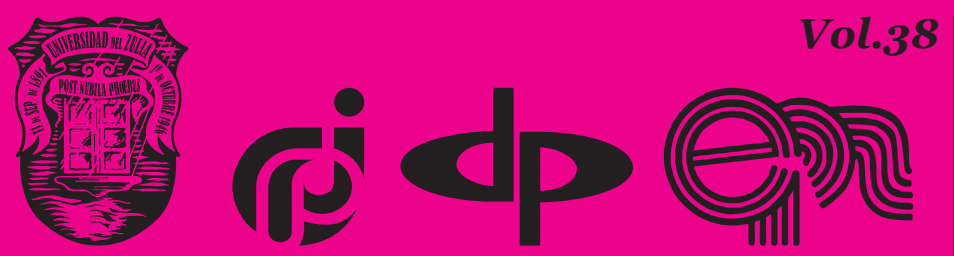

$N^{\circ}$ Especial 1era Parte 2020 


\title{
Latino and Central American Asylum Seekers in the United States of America During the Trump Administration
}

\author{
DOI: https://doi.org/10.46398/cuestpol.38e.27
}

\section{Sina Mohammadi *}

\begin{abstract}
The purpose of the article was to examine the Trump administration's asylum policy applied to Central American and Latino applicants. The United States has grappled with refugee problems in recent decades, and in 2018 Trump signed an executive order to detain families seeking to immigrate to the United States without separating from one another. With this decree, a new approach was formed in the policy of the United States government, which emphasizes the severe restrictions on the entry of asylum seekers and immigrants. In the methodological, it is a documentary research close to hermeneutics. It is concluded that, although the United States government has cited security concerns as an excuse to restrict the entry of asylum seekers, especially Latinos from Central American countries, this political approach is in conflict with the national legislation of the United States that stipulates that any citizen Foreigner arriving at any point along the US border, or at official exit points, has the right to apply for asylum. Furthermore, the implementation of such a policy is contrary to the end of the 1951 Convention, which focuses on the
\end{abstract} protection of refugees without distinction.

Keywords: Asylum seekers; Latin Americans; Central American countries; United States of America; Trump administration. 


\section{Solicitantes de asilo latinos y centroamericanos en Estados Unidos de América durante la administración Trump}

\section{Resumen}

El objetivo del artículo fue examinar la política de asilo de la administración Trump aplicada a solicitantes centroamericanos y latinos en particular. Estados Unidos se ha enfrentado a problemas de refugiados en las últimas décadas, y en 2018 Trump firmó una orden ejecutiva para detener a las familias que buscan inmigrar a Estados Unidos sin separarse unas de otras. Con este decreto, se formó un nuevo enfoque en la política del gobierno de Estados Unidos, que enfatiza las severas restricciones a la entrada de solicitantes de asilo e inmigrantes. En lo metodológicos se trata de una investigación documental próxima a la hermenéutica. Se concluye que, aunque el gobierno de Estados Unidos ha citado preocupaciones de seguridad como una excusa para restringir la entrada de solicitantes de asilo, especialmente latinos de países centroamericanos, este enfoque político está en conflicto con la legislación nacional de norteamericana que estipula que cualquier ciudadano extranjero que llegue a cualquier punto de la frontera de EE. UU., o en puntos de salida oficiales tiene derecho a solicitar asilo. Además, la implementación de tal política es contraria al final de la Convención de 1951, que se centra en la protección de los refugiados sin distinción.

Palabras clave: Solicitantes de asilo; latinoamericanos; países centroamericanos; Estados Unidos de América; administración Trump.

\section{Introduction}

The issue of the displacement of some 70 million IDPs who have inadvertently relocated within or beyond the borders of governments, and suffering from a lack of freedom, security and minimal living facilities, and are pursued with special sensitivity by the international legal system. In the current era, which has sought to protect the status of humanity more than ever for the rule of international law. Acknowledging the fact that every two seconds a person is forced to leave their home due to government harassment and armed conflict is very worrying. In this regard, international law specifically supports the status of some 30 million refugees and asylum seekers under a cohesive system. This legal system, with the mechanism of binding treaties, international custom, as well as soft legal resources at the international, regional, and national levels, provides protection to refugees, and imposes certain obligations and rights on governments. 
However, when asylum applications do not flow individually and within administrative disciplinary proceedings, but collectively to a single state, a new situation will arise that is called a Mass influx in the doctrine of International Law. In this situation, groups of several thousand and sometimes several million asylum seekers approached the borders of the governments and applied for asylum for fear of endangering their lives and freedom. The latest example of this Mass influx, the influx of asylum seekers from Honduras, Guatemala and El Salvador through Mexico into the United States in $\mathbf{2 0 1 8}$ was met with a negative response from the US government and the deployment of troops to counter the aforementioned population.

The most important legal arguments of the United States of America have been based on the following: Failure of the United States to ban the return of asylum seekers who have not yet entered the United States, and the non-compliance of the United States with asylum applications outside the official points of departure in to the United States.

\section{The Concept of Refugee and Asylum}

Under the 1951 Refugee Convention, an asylum seeker is a person who is a citizen of a foreign country due to justified fear of persecution for racial, religious, or national reasons, membership in a particular social group, or political affiliation, and because of this fear, he cannot or does not want to be supported by the government.

An asylum seeker in the asylum system refers to a person who is seeking asylum for the same reasons as defined in the refugee definition but has not yet been identified as a refugee. The term is used to describe the legal status of the time gap between the date of asylum application by the asylum seeker and the date of asylum approval by the receiving state. Although it is clear by logic that not every refugee will necessarily be a refugee, under international law, asylum seekers have certain rights and privileges until their asylum application is determined on a temporary basis (Kayhanlou and Dadmehr, 2020).

A refugee is always someone who does not have the support of his or her government. Thus, the lack of support is seen as a source of fear for refugees. Conditions for asylum status will not be met whenever a person is able to avoid "justified fear of being harmed for reasons related to race, religion, nationality or membership in a particular social group or political opinion." Go to your respective government and get support. As one of the asylum seekers says: As long as the asylum seeker proves to have significant national support, there is no fear of persecution (Hathaway recited in: european legal network on asylum, 1998). 
Lack of government support is one of the most important aspects of all the treaties, treaties and protocols adopted in the field of protection of refugees of special origin or citizenship in the years prior to the ratification of the 1951 Convention.

The definition of asylum at the 1951 UN Convention on the Status of Asylum is as follows: Refugees are those who live abroad for reasons of fear of being harassed for reasons related to race, religion, nationality, membership in a particular social group, or political opinion, and because of that fear, he doesn't want to be under the protection of that country or if he doesn't have citizenship. As a result of these incidents, he is living abroad, due to this fear, he does not want to return to it or is unable to return (United Nations Convention relating to the Status of Refugees, Art (A).

According to the UN High Commissioner for Refugees (UNHCR), seeking asylum abroad is a common condition for asylum. As refugees, those who have left the country of origin are supported. The decision to leave and cross the border where the person has lost or been deprived of the protection of his or her home country and needs another source of support makes the person the subject of international asylum law. Therefore, as long as a person is in the area of territorial jurisdiction of his or her home country, he or she cannot enjoy international protection. However, the judiciary does not allow asylum seekers to travel around the world in search of their preferred country. Asylum seekers who are afraid of being harassed are expected to apply for asylum from the first safe country they enter.

The fact that an asylum seeker must be abroad in order to be considered a refugee does not necessarily mean that he or she must have left the country legally or even for justified reasons. Individuals can apply for asylum after living in a foreign country for some time due to their activities in the home country.

However, it should be noted that the likelihood of success of refugee cases will be greatly reduced if these activities and actions are deliberate in order to influence the flow of asylum status (Kayhanlou, 2010).

Migrant is a person who, although as a refugee and asylum seeker, has left his homeland and in this respect has a certain common denominator with one of the components of asylum. Migrant are exempt from the two main components of asylum: justified fear and harassment. In other words, an immigrant is a person who leaves his or her country of citizenship for mainly personal reasons and in order to improve his or her quality of life in order to find a job, study, and so on. Unlike asylum seekers and refugees, Migrant will continue to enjoy the support of their respective governments when they leave the country (Kayhanlou and Dadmehr, 2020). 
Sina Mohammadi

Latino and Central American Asylum Seekers in the United States of America During the Trump

410

Administration

\section{Refugee Support}

Asylum seekers fleeing in search of a safe place in their home country, on the one hand, the variety of lawsuits filed by these individuals, and on the other hand, the ambiguity in the definition of refugees as enshrined in the 1951 Geneva Convention on the Status of Refugees -as the only international enforcement document in this regard - has forced the domestic courts of asylum-seeking countries. To perform their judicial function in resolving asylum claims, they must interpret the definition of a refugee in the domestic law of their country, which is in fact borrowed from the 1951 Convention (Kayhanlou, 2007).

The 1951 UN Convention on the Status of Asylum "considers whether or not a refugee is eligible for protection" The government concerned has considered the main conditions for granting asylum. The condition, which apparently entrusts the asylum seeker with a refugee status, has been interpreted as a "lack of government support" in refugee cases.

Therefore, by proving the lack of government support, the individual's inability, or willingness to have proven support is assumed, and the government's intention is to replace the individual's intention. Lack of government support is proven when an asylum seeker proves that, in addition to being abroad, he or she has sought support from government officials, but it did not have it, and it was not possible to resort to the option of internal escape (Kayhanlou, 2010).

The term "inability or unwillingness to be supported by the respective government" was first used in the Statute of the International Organization for Migration (2.I.R.O. Constitution, Annex I, Part I, Sec.A).

The High Commissioner for Refugees (UNHCR) based its definition on the status of refugees during the preparation of the Code of Conduct and the criteria for determining the status of asylum seekers.

"The inability to deal with support implies a situation that is beyond the control of the person concerned.

For example, a state of war, civil war, or other severe unrest can prevent an asylum seeker from spreading or make that support ineffective.

"This denial of support confirms or reinforces the asylum seekers fear of harassment and, in fact, can be an element of harassment."

The term reluctance refers to refugees who refuse to accept the support of their respective governments. The word is tied to "The cause of this fear" the propensity to be supported by the government is usually at odds with 
the claim of being abroad "because of justified fear of being harassed." If the government may have the support of the government and there is no reason to reject it due to justified fear, that person does not need international and refugee support (UNHCR, 1992: 98).

\section{Immigration to America}

From the beginning, the United States has been one of the most immigrant-friendly countries in the world. It has always covered its population shortages and fertility rates by accepting Migrants. An important feature of US immigration policy is that it is contingent. At various points in time, the US Congress has revised and amended laws to suit the economic conditions of the time, the fertility rate, the need for labor, and the conditions for applicants to Migrant to the United States. From the end of World War II until the early 1960s, American immigrants and refugees included various European, Asian, Canadian, and Latin American nationalities.

With economic and political stability and increasing prosperity in European and Asian countries, in recent years the origins of immigrants to the United States have changed from those countries to Mexico and the poor countries of Latin America. So, in the last two decades, the country has been pursuing policies to prevent the entry of Mexican and Latin Migrants due to the disappearance of immigrant diversity and the influx of immigrants entering the United States from poverty and exorbitant costs. From this time onwards, with the increase in the welfare of European countries, the number of immigrants from these countries has decreased and it has increased to the number of Migrants from Latin American and communist countries.

In recent years, with the abolition of communist regimes, much of the legal and illegal Migrants to Central and Latin American countries has become a major concern for US governments. In 1996, Bill Clinton passed Congress on the illegal Immigration Reform Act, based on proposals from the Immigration Regulatory Commission. The law also imposed strictures on illegal Migrations living in the United States. For example, under the law, people who have been in the United States illegally for six months to one year at the time of their arrest It was not allowed to enter the United States for three years, and this number increased to 10 years for people who had spent more than a year in the United States illegally. Also, before the law, illegal Migrations were imprisoned for at least five years before being deported only if they committed a serious crime. Under the law, illegal Migrations who have committed minor crimes, such as to snatch a bag, were sentenced to six months to two years in prison, depending on the type of crime. 
On the other hand, in recent years, the origin of immigrants to the United States has changed from these countries to Mexico and the poor countries of Latin America. So in the last two decades, the country has been pursuing policies to prevent Mexican and Latin immigrants from entering the United States due to the disappearance of immigrant diversity and the influx of immigrants entering the United States from poverty and exorbitant costs. But the high fertility rates of these immigrants, family visa applications, and the 3200-kilometer border between the United States and Mexico, which has made it possible for illegal entry, have become a major issue for racial change for decades to come.

George W. Bush tried to legalize the residence of some illegal immigrants by defining certain conditions and paying fines but failed. Obama has tightened ground entry into the United States, and with two programs, Dapa and Dasa, has tried to allow a number of illegal immigrants to work to encourage less-rooted immigrants in the United States. The Trump administration is also trying to reduce the number of illegal immigrants by enforcing the 2006 Mexican Wall Act and adding austerity to illegal immigrants, such as long-term deportations and imprisonment (Report, 2018).

The number of deportations of illegal immigrants and refugees in 2017 has halved compared to 2010. This is not about reducing border forces or facilitating entry into the United States. According to Bloomberg, Obama's connection, and influence with anti-immigrant people in the United States is one of the main reasons for the tightening of the Obama administration. On the other hand, Trump's policy, rather than dismissal, is based on toughening on refugees and illegal immigrants if the slightest violation of the law is done, which in itself has created fear and reduced immigration from the southern borders.

Another of Trump's goals is to employ American employers who are subject to harsh penalties if they hire illegal immigrants. Also, according to a law passed by Congress in August 2017, the annual number of green cards was halved, and the permitted ceiling for refugees was reduced to 50,000 annually (ibid: 22). Thus, the tough policies that began in the field of immigration and asylum from the Clinton era have become a critical issue under Trump's command. The number of deportations of illegal immigrants and refugees in 2017 has halved compared to 2010.

This is not about reducing border forces or facilitating entry into the United States.

Latin American asylum seekers invade US borders

In 2018, Trump signed an executive order to stop families planning to immigrate to the United States without separating from each other. Trump has vowed that not separating immigrant families from each other will not 
overshadow his "very strong borders" policy. This makes it clear that the crisis of mass arrests and deportations across the border and throughout the United States will continue. The President's November 9, 2018 decree stipulates that anyone seeking asylum in the United States must enter the country from official points of departure, and that if they have entered the United States illegally, their asylum application will not be processed.

The decree was to run for 90 days, during which time the United States would reach an agreement with Mexico on the return of asylum seekers. Under US law, asylum seekers are required to apply for asylum seekers who have fled their country to escape violence, and do not depend on their place of entry into the United States. Thus, the presidential decree practically meant the suspension of this law for ninety days.

The mass influx of asylum seekers from South America to the United States is not in itself a new phenomenon. In the 1980s, thousands of South Americans took refuge in North America. This movement used to take place in the form of caravans that did not exceed a few hundred people in number, and for this reason, their passage was not very visible. But what sets the 2018 convoy apart from other caravans is the significant number of members, which is estimated at 7,000. When the convoy crossed the Honduras and Guatemala into the Mexican border to reach the United States, in a public statement, the president described the convoy's entry into the United States as a threat to US national security and ordered troops to block the entry of foreigners into the country by blocking the shared border with Mexico.

This happened at a time when the convoy included a large number of asylum and immigration applicants, and as noted, the principles governing immigration law are fundamentally different from asylum law. Trump issued a statement on November 9 expressing concern over the security threat to the US convoy, saying the United States was reluctant to process asylum applications except at official points of departure. He suspended the passage of foreigners (both immigrants and asylum seekers) across the US-Mexico border for 90 days. In this regard, while acknowledging the difficulties of the United States in responding to the foreign population who have reached the borders of this country, the UN High Commissioner for Refugees (UNHCR) has stated that blocking the border on the convoy will harm those who have fled the country due to justified fears (Kayhanlou and Dadmehr, 2020).

Refugee rights from an international legal perspective. The discourse on the political rights of Migrant and refugees in legal circles and international institutions is flourishing. In the law of the countries of the world, talking about the political rights of Migrant and refugees is subject to the principle of reciprocity. In other words, the host country of Migrant and refugees will treat the citizens of this foreign country in the same way that the government of these Migrant and refugees will deal with the citizens of the host country of Migrant and refugees (Valipour, 2017). 
Sina Mohammadi

Latino and Central American Asylum Seekers in the United States of America During the Trump

Article 31 of the 1951 Geneva Convention provides for refugees who are living in the country illegally:

1. Contracting States which have threatened or resettled refugees directly from the territory in which they lived and whose liberty is threatened and who have entered or resided there without permission, they will not be punished for entering or staying in their land against the law, provided that (they) immediately submit to the relevant authorities, provide convincing reasons for the entry or illegal presence.

2. Contracting States shall not impose any restrictions on the movement of such refugees other than those necessary, this restriction will only apply if the status of such refugees in a refugee country has not been determined or they have not been allowed to enter another country.

Article 33 also prohibits the expulsion or reinstatement of refugees:

"None of the Contracting States shall in any way grant asylum to lands which may be related to race, religion or nationality, membership in a particular social group, or having political beliefs, life or liberty, is not threatened with deportation or reinstatement".

One of the most important rights of refugees, which has been emphasized, is the principle of not returning refugees to a country that has been expelled or forced to leave the country for various reasons. This principle has always been strongly supported by the United Nations and other relevant institutions. The first paragraph of Article 11 of the 1951 Geneva Convention states: "None of the Contracting States shall in any way intimidate or repatriate any asylum seekers to lands which may be endangered for reasons of race or life or liberty."

The United Nations Convention against Torture and Other Cruel, Inhuman or Defamatory conduct or Punishment states: "No government member of the Convention will return a person to another country where there is serious evidence of torture and danger to life." This principle is also emphasized in various international, regional and national resolutions and declarations. This internationally emphasized principle also has an exception, which is stated in the second paragraph of Article 33 of the 1951 Convention: "But a refugee whose existence is dangerous for the security of the receiving country or who has committed an important crime for sufficient and justified reasons will not enjoy the privilege of this article".

Therefore, as long as there are no favorable conditions for the return of refugees to their country, their return will be contrary to the various declarations and resolutions concerning refugees (Valipour, 2017). 


\section{Reasons for Us Rights in the Face of a Wave of Refugees}

Responding to the mass influx of asylum seekers has been one of the most important concerns of the international community, especially in recent years. It leaves a seal of approval on the assertion that approving the New York Declaration on Immigrants and Refugees by Government Decision with 193 votes in the General Assembly (September 19, 2016) and subsequently ratifying the International Refugee Convention with only 2 votes against the United States and Hungary in the final days of the General Assembly's annual activity (December 17, 2018).

Collective asylum not only creates a crisis for the receiving states but can also lead to widespread human rights abuses if they refuse to comply with the obligation to prohibit the return of asylum seekers. Historically, although the United States Government has not acceded to the 1951 Refugee Convention from the outset, it has accepted virtually all of its obligations under the 1967 Protocol. With the passage of the Asylum Act of 1980, which was annexed to the Immigration and Citizenship Act and the Immigration and Refugee Aid Act, the United States pledged to provide more protection to asylum seekers who leave their homeland for human rights violations under the 1967 Protocol.

In this regard, the US government, in accordance with the 1967 Protocol and the domestic law system, considers itself committed to the prohibition of the forced return of asylum seekers. Paragraph 1 of Article 8 of Article 243 of the U.S. Immigration and Citizenship Act makes the commitment under Article 33 of the 1951 Refugee Convention a domestic law. However, these domestic and international legal requirements did not preclude the United States from providing different interpretations of its obligations (ibid: 178).

\section{Background to Us Treatment of Asylum Seekers}

Then, just two years after the passage of the US Refugee Act in 1980, Reagan's administration launched an entry ban program that allowed the US Coast Guard to stop Haitian-owned ships, and prevent Haitian citizens from entering the United States through illegal immigration.

The only positive point of this program (the continuation of the US commitment to protecting asylum seekers) was canceled by the issuance of a similar program by George Bush, and it was decided that all Haitian nationals who illegally entered the United States would be returned to Haiti, regardless of their asylum application. By issuing an executive order 
in 1992, George Bush officially declared that the privileges of Article 33 of the 1951 Refugee Convention would not be granted to persons outside the borders of the United States. The United Nations High Commissioner for Refugees (UNHCR) has called the United States the first country in the world to adopt such a policy (Pizor and Sale, 1993).

Although the executive order was amended by the Clinton administration a few years later, Clinton also emphasized the principle of intra-territorial commitment to prohibit the return of asylum seekers so that the BushClinton asylum policy would be established in the US government. Following this process, the Council of Haitian Centers, along with several other institutions, filed a lawsuit against the US government's asylum policy in US domestic courts. However, the Supreme Court ruled that the provisions of paragraph 1 of Article 33 of the 1951 Convention, as well as the provisions of paragraph 1 of Article 8 of Article 243 of the US Immigration and Citizenship Act, only apply to asylum seekers within the territory of the United States.

As a result, George Bush's 1992 executive order does not conflict with domestic law, as well as US commitments under the 1967 Protocol. In the interpretation of Supreme Court of the United States, the word "return" in Article 33 was considered synonymous with dismissal and it was stated that the term should be interpreted in a narrow sense in relation to its common meaning. This is because in the 1951 Convention, the word is used interchangeably with the French word refoulement. The word is not considered an exact equivalent in any of the authoritative English and French cultures. Thus, in the view of the Americans, the most accurate and precise meaning is deportation, and one can be deported if one is within the country's borders.

The Court referred to the preliminary negotiations of the 1951 Convention and the objections of governments such as Switzerland, the Netherlands, Germany, and Italy to the interpretation of the word refoulement. It also emphasizes that the drafting authors of the Convention, by inserting this word in the text of Article 33, have sought to prevent the presentation of broad interpretations of the word "return" in a sense other than expulsion. In addition to emphasizing the intra-border commitment of Article 33, the US government also claims, except for paragraph 33 of Article 33, that the influx of asylum seekers poses security threats to the United States.

In this regard, the US government does not commit itself to complying with the principle of compulsory restitution. According to official statements from the White House and the US Department of Homeland Security, the convoy includes dangerous criminals and people from the Middle East who could pose a threat to US national security. 
The President of the United States considers this danger so serious that he does not deny the possibility of the use of firearms by the US military in response to possible violence by members of the caravan. Another US argument for justifying the president's statement on the suspension of travel from the Mexican border is that the US government does not have the legal right to accept asylum seekers anywhere they seek asylum, and it will only be responsible for the asylum seekers who enter the pre-determined points at the borders and there they will submit their application in the examination process (Kayhanlou and Dadmehr, 2020).

\section{The Principle of Prohibition of Forced Return of Asylum Seekers}

Many General Assembly resolutions also consistently support the principle of mandatory restraint. From the point of view of the General Assembly, the return or expulsion of asylum seekers in any way possible poses a threat to the very foundation of the refugee institution. In some of its resolutions, the General Assembly calls on governments to respect the prohibition of forced repatriation as an inviolable principle, and the Security Council has endorsed such a requirement even during the fight against terrorism or during armed conflict. The UN resolution explicitly extends the scope of the Declaration of Refugee Prohibition to the prohibition of returning to the borders, and the UN Security Council's resolution approving the elimination of international terrorism also emphasizes the importance of the prohibition of forced repatriation.

In a statement issued by the Prime Ministers of the Parties to the 1951 Convention and the 1967 Protocol in 2001, the States Parties reaffirmed that the principle of prohibition of reinstatement, as the core of the rights and obligations of the refugee system, is supported by international custom. The importance and legal implications of the decisions of such meetings and conferences held by the States Parties to the Treaty are set out in detail in the International Law Commission's Article 13 draft of the Future Plan for Future Performance and Subsequent Government Agreements (2018).

The Executive Committee of the United Nations High Commissioner for Refugees (UNHCR) has repeatedly stated in its decisions that deportation of refugees at the border is a gross violation of the obligation to prohibit reinstatement. In the Committee's view, this principle is generally accepted by governments at the international and regional levels. The Committee goes so far as to state in Resolution No. 25 of 1974 that the prohibition of compulsory restitution is increasingly becoming the International Law imperative (Allain, 2002). 


\section{Sina Mohammadi \\ Latino and Central American Asylum Seekers in the United States of America During the Trump 418 Administration}

The principle of prohibition on the return of asylum seekers under international treaty law and customary international law also includes the prohibition on the return of asylum seekers present behind territorial boundaries. Based on what has been seen from the performance of governments in creating hard and soft refugee legal resources, it can be concluded that governments should be committed to prohibiting the return of asylum seekers wherever they can exercise their effective competence, and the main criterion is not the placement of the asylum seeker inside or outside the country, but the placement of the asylum seeker under the effective control and authority of the governments. If this premise is correct, it can be accepted without a doubt that the general government has effective control over its territorial borders, and as long as it enjoys this border control and authority, it must abide by its contractual and customary obligations in the asylum system.

\section{Conclusion}

The United States' main claim that the obligation to prohibit restitution in Article 33 of the 1951 Convention is intra-border does not have a solid legal basis. In principle, the accepted mechanisms for interpreting treaties in international law, Articles 31 and 32 of the 1969 Vienna Convention, are intended to confirm the hypothesis of the obligation to prohibit the return of asylum seekers present at the borders. Obstruction of the border with asylum seekers is clearly one of the things that will harm the asylum seeker and force him to return to a country that endangers his life or freedom for racial, religious, national, and political reasons. Also, given the strong evidence that the restraining order is binding, the United States cannot have a solid basis for citing the exceptions set out in paragraph 2 of Article 33 of the 1951 Convention and defer the enforcement of the asylum caravan due to security threats. Although Article 33 recognizes two security exceptions as an excuse for states to enforce the principle of prohibition on the return of asylum seekers, the fundamental rule governing the reversal of obligations is that the reversal must be carried out in compliance with other international law. Therefore, the government's violation of the obligation to prohibit the forced return under the 1951 treaty will not affect the fulfillment of the same obligation in other legal systems, including the inalienable human rights system. If the receiving State knows that the asylum seeker's refusal will result in him or her being subjected to retaliation and endangerment, such as harassment and torture, he or she must not in any way dismiss the asylum seeker in accordance with his or her human rights obligations.

The United States has ultimately refrained from adhering to its commitment to ban asylum seekers from relying solely on official points 
of departure. This claim will not go unheeded by referring to US domestic law and the purpose and subject matter of the 1951 Convention. The policy of blocking the border and not accepting asylum seekers in undefined crossings conflicts with the laws that have been in place in the United States for nearly 40 years. According to it, the US Congress has explicitly stated that any foreign national who reaches any point on the US border or official points of departure has the right to apply for asylum. The 1963 textual amendment to the Asylum Procedure Act by Congress did not provide for an exclusive admission of asylum seekers on official grounds. In addition, the implementation of such a policy is inconsistent with the end of the 1951 Convention, which focuses on the protection of refugees.

\section{Bibliographic References}

ALLAIN, Jean. 2002. "The jus cogens Nature of non-refoulement" In: International Journal on Refugee Law. Vol 13, No 4, pp. 533, 538.

COLLECTION OF INTERNATIONAL INSTRUMENTS AND OTHER LEGAL TEXT SCONCERNING REFUGEES AND DISPLACED PERSONS. 1995. Published by Division of International Protection of the Office of the United Nations High Commissioner for Refugees, Geneva. Vol. I.

DAVODI, Hanieh; Maghsoudi, Tahmasb; Fami, Hossien Shabanali; Kalantari, Khalil. 2013. "Evaluation of strategies for developing the agriculture technology in the science and technology parks of Iran from faculty member aspect" In: African Journal of Agricultural Research, Vo. 8, No. 30, pp. 4148-4156.

HATHAWAY RECITED IN: EUROPEAN LEGAL NETWORK ON ASYLUM. 1998. "Research paperon non-satate agents of persecution". In: Up dated in Autumn 2000, No. 19, pp. 256-279.

KAYHANLOU, Fatemeh. 2007. "The Concept of Harassment Leading to Asylum in the Judicial Procedure of Refugee Countries" In: Journal of the International Law Center. No. 36, pp. 55-68.

KAYHANLOU, Fatemeh. 2010. "The Concept of Lack of Government Support in IN REFUGEE CASES” In: Law and Policy Research. Vol. 12, No. 28, pp. 114-129.

KAYHANLOU, Fatemeh; DADMEHR, Hadi. 2020. "Violation of US International Commitment to the Caravan of Asylum Seekers in Latin America” In: International Legal Journal. No. 6, pp. 16-39. 
PIZOR, Andrew G; SALE villiam.Haitian. 1993. "Centers Council: The Return of Haitian Refugee" In: Fordham International Law Journal. Vol 17, No. 4, pp. 59-86.

REPORT 1021. 2018. "Demographic Policies of the United States, President" In: Center for Development and Cooperation.

UNHCR.1992. Unher Handbook on Procedures and Criteria for Determining Refugee Status Under the 1951 Convention and the 1967 Protocol Relating to the Status of Refugees, Jan. 1992, HCR / IP / 4 / Eng / REV.1Reedited, Geneva, UNHCR 1979. Available online. In: https:// www.unhcr.org/4d93528a9.pdf. Consultation date: 15/11/2019.

VALIPOUR, Mohammad Ali. 2017. The Study of Refugee Rights from the Perspective of International Law. In: First International Conference on Jurisprudence and Law, Advocacy and Social Sciences, Hamedan, Permanent Secretariat of the Conference. 


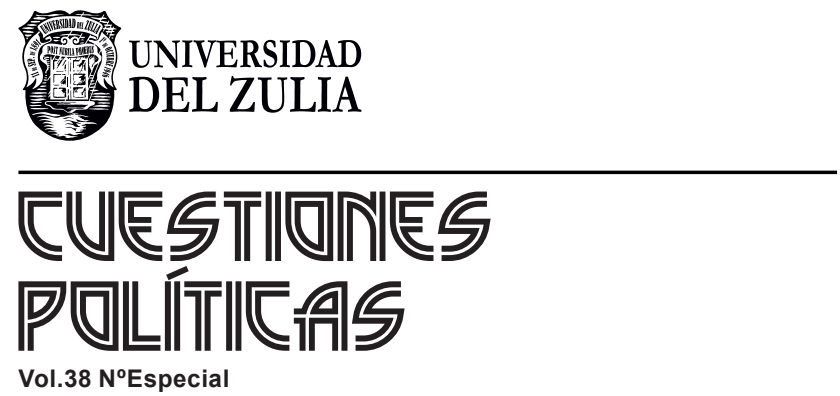

www.luz.edu.ve 